\title{
Correction to: Inequalities in Access and Utilization of Maternal, Newborn and Child Health Services in sub-Saharan Africa: A Special Focus on Urban Settings
}

\author{
E. M. Sidze ${ }^{1}$ - F. M. Wekesah ${ }^{1} \cdot$ L. Kisia' ${ }^{1}$ A. Abajobir ${ }^{1}$
}

Published online: 1 March 2022

(c) The Author(s) 2022

\section{Correction to: \\ Maternal and Child Health Journal (2022) 26:250-279 \\ https://doi.org/10.1007/s10995-021-03250-z}

The article "Inequalities in Access and Utilization of Maternal, Newborn and ChildHealth Services in sub-Saharan Africa: A Special Focus on UrbanSettings", written by E. M. Sidze, F. M. Wekesah , L. Kisia, A. Abajobir wasoriginally published electronically on the publisher's internet portal on 15 October2021 without open access. With the author(s)' decision to opt for Open Choice thecopyright of the article changed on 12 February 2022 to () The Author(s) 2021 and the article is forthwith distributed under a Creative Commons Attribution 4.0 InternationalLicense, which permits use, sharing, adaptation, distribution and reproductionin any medium or format, as long as you give appropriate credit to the originalauthor(s) and the source, provide a link to the Creative Commons licence, and indicateif changes were made. The images or other third party material in this articleare included in the article's Creative Commons licence, unless indicated otherwisein a credit line to the material. If material is not included in the article's CreativeCommons licence and your intended use is not permitted by statutory

The original article can be found online at https://doi.org/10.1007/ s10995-021-03250-z.

E. M. Sidze

esidze@aphrc.org

F. M. Wekesah

fwekesah@aphrc.org

L. Kisia

1.kkisia@gmail.com

A. Abajobir

aabajobir@aphrc.org

1 African Population and Health Research Center (APHRC), APHRC Campus, 2nd Floor, Manga Close off Kirawa Road, P.O. Box 10787-00100, Nairobi, Kenya regulationor exceeds the permitted use, you will need to obtain permission directly from thecopyright holder. To view a copy of this licence, visit http://creativecommons. org/licenses/by/4.0.

The original article has been corrected.

Open Access This article is licensed under a Creative Commons Attribution 4.0 International License, which permits use, sharing, adaptation, distribution and reproduction in any medium or format, as long as you give appropriate credit to the original author(s) and the source, provide a link to the Creative Commons licence, and indicate if changes were made. The images or other third party material in this article are included in the article's Creative Commons licence, unless indicated otherwise in a credit line to the material. If material is not included in the article's Creative Commons licence and your intended use is not permitted by statutory regulation or exceeds the permitted use, you will need to obtain permission directly from the copyright holder. To view a copy of this licence, visit http://creativecommons.org/licenses/by/4.0/.

Publisher's Note Springer Nature remains neutral with regard to jurisdictional claims in published maps and institutional affiliations. 